\title{
Publicações Científicas
}

\author{
Harley E. A. Bicas
}

O entendimento sobre o que seja um órgão de publicação científica é variado, tanto quanto múltiplas são as faces do próprio conhecimento que difundem, ou das necessidades dos leitores, aos quais se dirigem.

De fato, não é possível desejar que tenham mesmos formatos, condicionamentos, ou linguagem, em trabalho de Física Nuclear e outro de Cirurgia Plástica, um de Ciências "Básicas" e outro de "Aplicadas", um experimental e outro metanalítico e assim por diante. Nem convém a cogitação de se, para o mundo, o conhecimento teórico é mais importante que o prático, ou ao contrário. Pois um não se dissocia do outro: teorias são erigidas com base em conhecimentos empíricos, enquanto ilações pragmáticas resultam de análises abstratas. Indução e dedução são apenas processos pelos quais flui o conhecimento em uma ou outra direção: do particular para o geral ou viceversa. Que seria da roda se não houvesse o homem? Inútil como instrumento e nem sequer um conceito, pois não haveria a inteligência para apreciá-la...

Mas deixando as divagações filosóficas (entretanto agora já as aproveitando...) e voltando à questão inicial: como entender a finalidade dos Arquivos Brasileiros de Oftalmologia, o órgão de publicações científicas do Conselho Brasileiro de Oftalmologia? E a resposta, por sua obviedade, pode parecer tautológica: publicar ciência oftalmológica (o que supõe interessados: oftalmologistas e outros com motivações afins). Isto é, difundir todo conhecimento que contribua para um melhor conhecimento da Oftalmologia aos que por ela se interessam. Essa idéia, na prática, se consubstancia pela veiculação de matérias que:

a) apresentem estudos experimentais (laboratoriais ou clínicos), inovações instrumentais ou de procedimentos (diagnósticos e terapêuticos) e tudo que corresponda à criação de conhecimento original, inédito. São os assuntos "científicos" em sentido estrito, os artigos originais,

b) descrevam condições clínicas já conhecidas, mas raras (e com a justificativa de que se trate, por exemplo, de uma primeira publicação sobre o assunto no Brasil) ou desde que aduzam relações relevantes entre os aspectos conhecidos e ainda não observados; ou análises críticas a outros artigos. Tais matérias ("casos", "notas") também não diferem das que são publicadas em outros órgãos "científicos".

Mas privilegiar conhecimento não é só difundir inovações. Aliás, os avanços tecnológicos aparecendo vertiginosamente, em intervalos de tempo cada vez menores, e a enorme quantidade de novas informações e idéias deles decorrentes sendo maciçamente publicadas pelo mundo, tornam virtualmente impossível, mesmo ao "superespecialista"que dedica seu tempo a conhecer cada vez mais "quase tudo de quase nada", acompanhar o que vem se desenvolvendo em seu campo de interesse. Já se calculou que mesmo sem dormir e lendo todo tempo, não é mais possível tomar conhecimento (ciência) da ciência, ainda que numa área bem circunscrita.

Publicar ciência será então, também, organizar o caos de informações, apresentar de forma didática e ordenada o enorme conjunto de dados, entendê-los, interpretar seus direcionamentos. Em suma: oferecer resenhas, comentando-as. Parece brincadeira, mas não é: recentemente, uma agência nacional de fomento à pesquisa, em consulta a cientistas brasileiros por ela elencados como de alto nível, obteve deles, como resposta a quais seriam as publicações relevantes (de ciência, de divulgação científica) no Brasil, referências à "Veja"! Pensando bem, até que acertaram: uma revista de variedades, mas que noticia também avanços do conhecimento científico, digerido e democraticamente oferecido a todos...

Por essa razão e com muito carinho, os A.B.O. entendem essencial e cada vez mais importante, a instrução científica. Não a fundamental, mas a das contínuas transformações que sobre ela se erigem. E nesse sentido já vem, desde há algum tempo, dando espaço a artigos de "Atualização continuada" (assuntos específicos, condensados para proporcionar um aprimoramento de suas compreensões) e os de "Revisão Temática" (resenhas comentadas de publicações num determinado período sobre um dos grandes temas da Oftalmologia: Córnea, Conjuntiva, Cristalino, Retina, Vítreo, Úvea, Esclera, Estrabismo, Glaucoma, Neuro-oftalmologia, Ametropias e Presbiopia, Cirurgias Refrativas).

Principalmente sobre uma Revisão Temática, uma dificílima tarefa de análise e síntese conjugadas, as enormes dificuldades para concretizá-la, representadas pela extensão de consulta à literatura, pela experiência e critério requeridos na seleção do deve ser aproveitado, pelo discernimento crítico nos comentários a serem feitos e, enfim, pela disponibilidade de tudo equilibrar e redigir, tornam-se demandas pesadíssimas para uma única pessoa. É trabalho de equipe. Certamente sob uma coordenação mas, convenientemente, pluralístico. Essa a razão de passarmos a confiar tais matérias às respectivas Sociedades de "super" especialistas que poderão distribuir com mais eqüidade e apropriadamente as incumbências de trabalho.

Pois, como se diz, o progresso em ciência é, cada vez menos, fruto do trabalho de pessoas isoladas e, cada vez mais, resultado dos integrados por uma equipe. 